\title{
Study the economics of crop-livestock integrated farming system: A study of Hadoti Region of Rajasthan
}

\author{
Avdhesh Sharma* and P. S. Badal \\ Department of Agricultural Economics, Institute of Agricultural Sciences, Banaras Hindu University, \\ Varanasi (U.P.) India (Email: avdhesh.sharma2@bhu.ac.in)
}

\begin{abstract}
An integrated Farming system is the basic need of today. A survey of farmers was conducted in 2020-21 covering the Kota, Bundi, Baran, and Jhalawar districts of southern Rajasthan. Crop-livestock farming systems were adopted by most of the farmers in the study area. Cereals, legumes, and oilseed were the major crops that were sown. The farmer of this region (Hadoti) practiced livestock rearing along with crop cultivation which had significant contributions as their primary source of income. The gross income per hectare from Soybean, black gram, wheat, and gram was Rs. 34,645.23, Rs. 28,150.61, Rs. 64268.78 and Rs. 47543.00, respectively. The cost was calculated using the Cost concept as suggested by CACP. Using livestock as one more enterprise farmers' was able to generate higher profit shown in the study. B:C ratio for IFS was 1.3 which was a good sign for the farming enterprise.
\end{abstract}

Key Words : IFS, Cost concept, Livestock, Economics

View Point Article : Sharma, Avdhesh and Badal, P.S. (2021). Study the economics of crop-livestock integrated farming system: A study of Hadoti Region of Rajasthan. Internat. J. agric. Sci., 17 (AAEBSSD) : 34-40, DOI:10.15740/HAS/IJAS/17-AAEBSSD/34-40. Copyright @ 2021: Hind Agri-Horticultural Society.

Article History : Received : 08.07.2021; Revised : 11.07.2021; Accepted : 13.07.2021

\section{INTRODUCTION}

Through the integrated farming system, the country has come up with its own version of the concept of "doubling farmers' income". The IFS, which will be implemented as part of the National Agriculture Development Programme (NADP), will compel every farmer to engage in a variety of activities other than agriculture in order to earn a higher income than they would have earned under traditional farming methods. The total milch animal population in the country was 192.49 million in 2019 (Livestock census, 2019).By 2050, global demand for dairy and meat is projected to extend by $74 \%$ and $58 \%$ respectively, and an outsized a part of this demand will originate from developing countries (FAO, 2012).In developing countries like India, the farming system concept is a valuable instrument for managing natural and human resources (Rana, 2015).

The increased contribution of the livestock industry to the agricultural gross domestic product has been one of the most significant changes in India's agricultural economy over the last three and a half decades

\footnotetext{
* Author for correspondence :
} 
(Kumawat et al., 2014). Indian agriculture is labour intensive, hence, it requires a lot of manpower and energy. But even after this hard work, farmers are not in a position to attain a good standard of living, especially small farmers because there is very little left after they are responsible for all inputs (seeds, livestock breeds, fertilizers, pesticides, energy, feed, labour, etc.). The government has launched several schemes and policies to increase the income of the farmer. Rajasthan government has subsidized the purchase of solar irrigation systems to save irrigation costs and also increases the income of farmers from crop enterprises. Replacement of 14 HP diesel pump by a solar irrigation pump saved Rs. 36,600 per farm in the selected cropping system (Gautam et al., 2020). Similarly, different interventions are needed to achieve an increase in farmer's income.To provide the essential needs of farm families, such as food (cereals, pulses, oilseeds, milk, fruit, honey, meat, etc. ), feed fodder, fibre, and fuel, the integrated farming system (IFS) must be considered (Sanjeev Kumar et al., 2018). IFS has many advantages over monoculture (Kiran Reddy et al., 2020). Milk is a key primary source of revenue for India's 70 million dairy farming households (Sunil et al., 2019).

Rajasthan is the largest state in the country and stands at 4th position concerning total food grain production in the year 2019-20 (Indiastat, 2020-21). The basic aim of an integrated farming system is to derive a set of resource development, management, and utilization practices that lead to a substantial and sustained increase in agriculture production (Singh et al., 2013). In agriculture, "Integrated Farming Systems (IFS)" holdsa special position because in this system nothing is wasted. One system's by-product becomes the input for another.Crop wastes can be used as milch animal feed, and milch animal dung can be used to improve soil tilth, fertility, and carbon sequestration, all of which can improve agricultural output (Reddy, 2016).

An integrated farming system reduces erosion, increases crop yields, soil biological activity, and nutrient recycling, reduces inefficient water use, reduces pest and disease, intensifies land use, and improves profits, and thus can help reduce poverty and malnutrition while also strengthening environmental sustainability (Walia and Kaur, 2013). The Integrated Farming System (IFS) is crucial in increasing profit and productivity in order to meet nutritional needs while maintaining food security with minimal expenditure (Sunil Kumar et al., 2014).The Integrated Farming System (IFS) is crucial in increasing profit and productivity in order to meet nutritional needs while maintaining food security with minimal expenditure. (Indira, 2017). crop residues can be used for milch animal feed, while manure from livestock can enhance agricultural productivity by intensifying nutrients that improve soil fertility as well as reducing the use of chemical fertilizers (Gupta et al., 2012). Diverse enterprises complement each other for food, nutritional security, and soil health, economic and environmental sustainability. The present article analyses the cropping pasture integrated farming system. It gives an idea of the benefit and cost of crop-livestock integration, and opportunities. Detailed economics is given further on a product-by-product basis.

\section{Material AND Methods}

Four major crops of the study are a were selected for analysis. The crops were namely soybean, black gram from Kharif crops and wheat and gram were taken from Rabi season crops. The analysis was done by using the CACP (Commission of Agricultural Cost and Prices) cost concept. To estimate the costs and returns of milch animals, all the fixed and variable costs involved in livestock rearing were estimated.Devaluation was

\begin{tabular}{|lccc|}
\hline \multicolumn{2}{|l|}{ Table A: Sampling procedure flow chart } & & \\
\hline State & District & Block & Village \\
\hline \multirow{3}{*}{ Kota } & Khairabad & Sonkheda, Modak Gaon \\
& Ladpura & Badgaon, Balita \\
& Bundi & Keshoraypatan & Rangpuriya, Ishwar Nagar \\
& & Taleda & Itoda, Karad Ka Bardha \\
Rajasthan & Anta & Kundla, Shahpura \\
& Baran & Baran & Nareda, Baman Mata kiJhonpadi \\
& \multirow{2}{*}{ Jhalawar } & Khanpur & Sarkandiya, Panwar \\
& Dug Gangdhar & Salariya, Harnikheda \\
\hline
\end{tabular}


determined by a straight-linestrategy. The yearly depreciation on the shed was determined at the rate of 2 $\%$ for ' $p u c c a$ ' shed and $10 \%$ for ' $k a c h h a$ ' shed by assuming the better life of ' $k a c h h a$ ' shed as 10 years and 50 years for ' $p u c c a$ ' shed (Rao, 1991). The interest rate on fixed capital was calculated at the rate of the commercial bank. Part of labour cost is computed based on wage rates as suggested by Kumbhare et al. (1983). Veterinary and miscellaneous costsi.e. light, fuel, annual repair, etc. are taken into the account.

To assess the economics of crop cultivation and livestock milk production, a primary survey was undertaken in the hadoti region of Rajasthan state by using the stratified random sampling technique for the study. In hadoti region, four districts are included which are Kota, Bundi, Baran, and Jhalawar of Rajasthan. Khairabad and Ladpura block from Kota district, Keshoraypatan and Taleda blocks from Bundi district, Baran and Anta block from Baran district, Khanpur and Dug Gangdhar blocks from Jhalawar district were selected randomly. The flow chart of sampling procedure presented in Table A. Two villages were selected randomly from each block and farmers from each village as presented below:

Data was collected by using a pre-tested and wellstructured interview schedule. Collected data were corresponding to the year 2020-21.

\section{RESUlTS AND DisCUSSION}

The results obtained from the present investigation as well as relevant discussion have been summarized under following heads :

\section{Economics of crop production :}

The expenses incurred on the crops were categorized into four groups i.e. operational cost, fixed cost, managerial cost, and total cost. Fixed cost includes the rental value of land, rent paid for leased-in-land, land revenue, taxes, cesses, depreciation, and interest on fixed capital. In variable cost included the cost of seed, sowing, fertilizer, irrigation, weeding, harvesting, thrashing, and other miscellaneous charges. Average per-hectare total expenses on different crops by farmers were computed which was presented in the Table 1 . It was observed from Table 1 that the average cost of soybean production was Rs. 29,013.50 per hectare out of that Rs. 21,094.83 was total operational cost and Rs. 5,281.07 was fixed cost. In other crops black gram having Rs. 24,101.12,
Rs. $14,810.58$, and Rs. 7,099.53 were fixed, operational and total costs, respectively. For the wheat crop,the operational cost was 28,519.14, the fixed cost was Rs. 13455.05 and the total cost was Rs.46,171.60. Rs. $23,151.93$ was operational cost, Rs.8789.19 was fixed and Rs.35,135.23 was the total cost for the gram crop.

\section{Income or Returns from Crop Production:}

Cost and Income measures of different crop cultivation are presented in Table 2. The gross income per hectare, on an average worked out forSoybean (Rs. 34,645.23), Black Gram (Rs. 28,150.61), Wheat (Rs. 64,268.78), and Gram (Rs. 47,543.00). It was highest inthe case of Wheat crop and lowest for Black Gram. Net return was higher in the case of wheat and for Black gram, it was lowest.

\section{Economics of Milk Production :}

The cost and returns analysis was carried out based on cost concepts. Dairy farming costs were calculated as, Variable cost (Cost A) by the sum of Cost of green fodder, dry fodder, concentrates, upkeep labour (hired), veterinary and medicines, and other miscellaneous costs. The fixed cost was carried out by adding together depreciation ofmilch animal value, milch animal-shed value, and milch animal equipment value, interest on milch animal values, interest on shed values, and interest on equipment values. The total variable cost per milch animal was Rs.189.37/day which accounts for 86.42 per cent of the gross cost. Similar findings were reported in the previous studies also (Umamageswari et al., 2017). Fixed cost (Cost B) was Rs.29.75/day. The total cost was Rs.219.12/ day,carried out by sum of both Cost A and Cost B. Net cost calculated by using Gross costthe value of dung in rupees which was Rs.209.48/day.

\section{Income or returns from milk production :}

Income or returns from milk production per day are presented in Table 4 for the farmers of hadoti region. Milk production per milch animal per day in the study area was 6.32 litres per day. Profit from selling the milk per litre was Rs. 45.41. Gross return from milk per milch animal per day was Rs. 286.99. The cost per litre was Rs. 33.01 which is consistent with the earlier studies carried out by (Lal, Priyanka and Chandel, 2016).

The Gross return per milch animal for the whole lactation period was showing in Table 5. Total milk production was found 2527.05 litres which accounts for 
Avdhesh Sharma and P. S. Badal

\begin{tabular}{|c|c|c|c|c|c|c|}
\hline \multicolumn{7}{|c|}{ Table 1: I tem wise Breakup of the Cost of Production (Rs./hac.) } \\
\hline & \multirow{2}{*}{\multicolumn{2}{|c|}{ Costs }} & \multicolumn{4}{|c|}{ Amount } \\
\hline & & & Soybean & Black Gram & Wheat & Gram \\
\hline \multirow[t]{2}{*}{ A } & \multirow[t]{2}{*}{ Operational Cost } & & $21,094.83$ & $14,810.58$ & $28,519.14$ & $23,151.93$ \\
\hline & & Family & $4,945.34$ & $4,119.13$ & $10,797.13$ & 5426.23 \\
\hline \multirow[t]{4}{*}{1} & \multirow{3}{*}{ Human Labour } & Attached & 0.00 & 0.00 & 0.00 & 0.00 \\
\hline & & Casual & 906.82 & $1,892.49$ & 27.21 & $4,453.90$ \\
\hline & & Total & $5,852.16$ & $6,011.62$ & $10,824.38$ & $9,880.13$ \\
\hline & & Hired & 0.00 & 0.00 & 0.00 & 0.00 \\
\hline \multirow[t]{3}{*}{2} & Milch animal Labour & Owned & 41.73 & 0.00 & 26.26 & 0.00 \\
\hline & & Total & 41.73 & 0.00 & 26.26 & 0.00 \\
\hline & & Hired & $7,371.44$ & $3,621.69$ & $1,983.35$ & $1,538.37$ \\
\hline \multirow[t]{2}{*}{3} & Machine Labour & Owned & $1,209.88$ & $1,739.99$ & $2,021.49$ & $1,817.63$ \\
\hline & & Total & $8,581.32$ & $5,361.69$ & $4,004.84$ & $3,355.93$ \\
\hline \multirow[t]{2}{*}{4} & Seed & & $4,034.27$ & $1,409.32$ & $3,227.69$ & $4,197.40$ \\
\hline & & Fertilizer & 601.70 & 839.92 & $3,076.20$ & 249.64 \\
\hline \multirow[t]{2}{*}{5} & Fertilizer and Manure & Manure & 0.00 & 0.00 & 0.00 & 0.00 \\
\hline & & Total & 601.70 & 839.92 & $3,076.20$ & 249.64 \\
\hline 6 & \multicolumn{2}{|l|}{ Insecticides } & $1,542.71$ & $1,014.68$ & 105.59 & 613.02 \\
\hline 7 & \multicolumn{2}{|l|}{ Irrigation Charges } & 197.68 & 0.00 & $6,925.26$ & $4,588.75$ \\
\hline 8 & \multicolumn{2}{|l|}{ Miscellaneous } & 0.00 & 2.57 & 0.04 & 0.00 \\
\hline 9 & \multicolumn{2}{|c|}{ Interest on Working Capital } & 243.27 & 170.80 & 328.89 & 266.99 \\
\hline B & \multicolumn{2}{|l|}{ Fixed Costs } & $5,281.07$ & $7,099.53$ & $13,455.05$ & $8,789.19$ \\
\hline 1 & \multicolumn{2}{|c|}{ Rental Value of Owned Land } & $4,426.48$ & $4,301.19$ & $11,269.79$ & $6,346.12$ \\
\hline 2 & \multicolumn{2}{|c|}{ Rent Paid For Leased-in-Land } & 0.00 & 0.00 & 0.00 & 0.00 \\
\hline 3 & \multicolumn{2}{|c|}{ Land Revenue, Taxes, Cesses } & 6.97 & 8.77 & 6.05 & 10.76 \\
\hline 4 & \multicolumn{2}{|c|}{ Depreciation on Implements and Farm Building } & 677.27 & $2,560.55$ & $1,745.17$ & $2,148.79$ \\
\hline 5 & \multicolumn{2}{|l|}{ Interest on Fixed Capital } & 170.36 & 262.07 & 434.03 & 283.52 \\
\hline $\mathrm{C}$ & \multicolumn{2}{|c|}{ Operational Cost + Fixed Cost $[\mathrm{A}+\mathrm{B}]$} & $26,375.90$ & $21,910.11$ & $41,974.18$ & $31,941.12$ \\
\hline $\mathrm{D}$ & \multicolumn{2}{|l|}{ Managerial Cost } & $2,637.60$ & $2,191.01$ & $4,197.42$ & $3,194.11$ \\
\hline $\mathrm{E}$ & \multicolumn{2}{|l|}{ Total Cost $[\mathrm{C}+\mathrm{D}]$} & $29,013.50$ & $24,101.12$ & $46,171.60$ & $35,135.23$ \\
\hline
\end{tabular}

\begin{tabular}{|c|c|c|c|c|}
\hline \multirow{2}{*}{ Particulars } & \multicolumn{4}{|c|}{ Crops } \\
\hline & Soybean & Black Gram & Wheat & Gram \\
\hline Total Variable cost & 21094.83 & 20234.82 & 28519.14 & 23151.93 \\
\hline Total Fixed Cost & 5281.07 & 7099.53 & 13455.05 & 8789.19 \\
\hline Total Cost & 29013.49 & 24101.12 & 46171.60 & 35135.23 \\
\hline Gross Return & 34645.23 & 28150.61 & 64268.78 & 47543.00 \\
\hline Net Return & 5631.73 & 4049.49 & 18079.18 & 12407.77 \\
\hline
\end{tabular}


Study the economics of crop-livestock integrated farming system

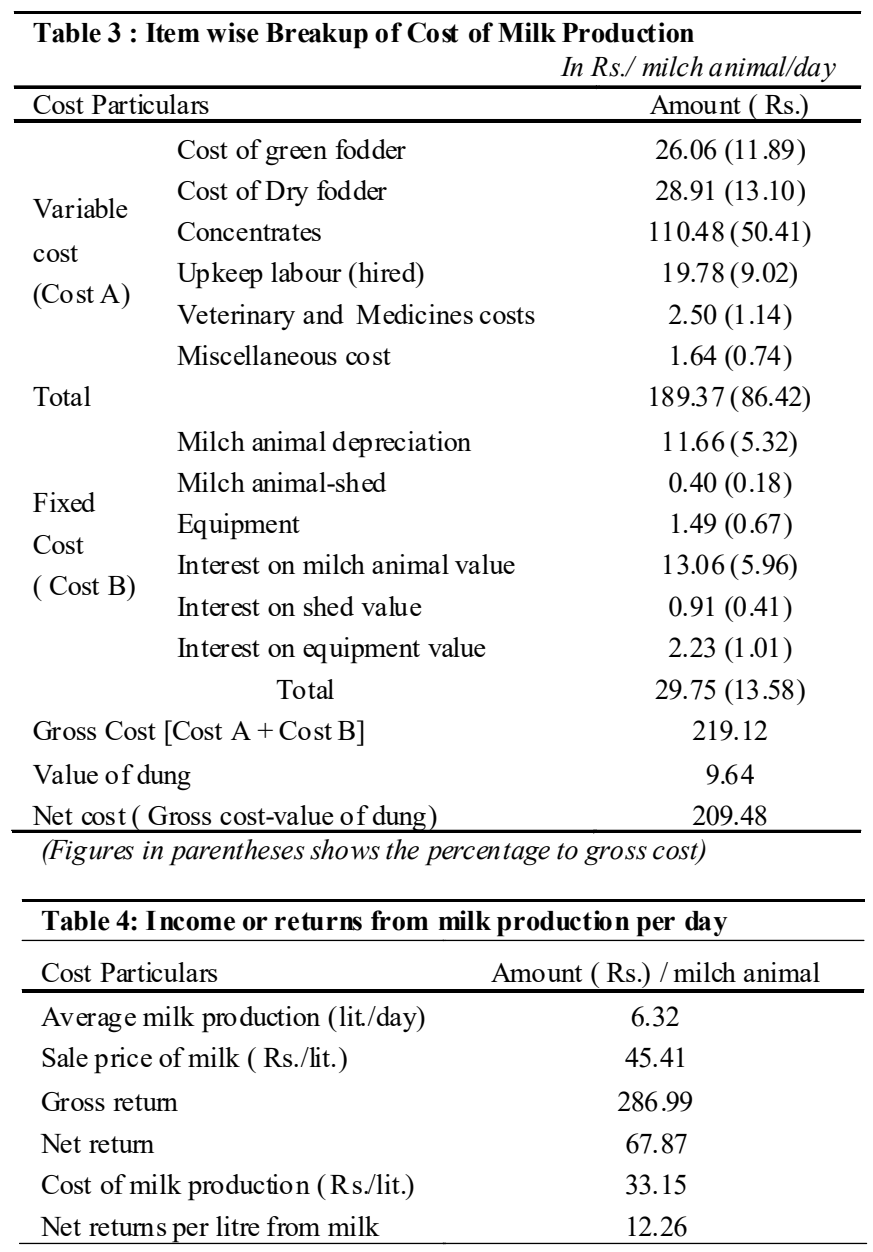

\begin{tabular}{|c|c|}
\hline \multicolumn{2}{|c|}{$\begin{array}{l}\text { Table 5: Average Income or returns from mil k production per } \\
\begin{array}{ll}\text { lactation period } & \text { In } R \text { s./milch anim al/lactation period }\end{array}\end{array}$} \\
\hline Particulars & Amount ( Rs.) \\
\hline Total Milk Production per lactation (ltr.) & 2527.05 \\
\hline Rate of milk per litre ( Rs.) & 45.41 \\
\hline Total Profit from milk per lactation ( Rs.) & 114753.34 \\
\hline Total profit from dung ( Rs.) & 4000 \\
\hline Total Profitper lactation ( Rs.) & 118753.34 \\
\hline Total cost per lactation period & 84978.07 \\
\hline Net income per lactation ( Rs.) & 33775.27 \\
\hline
\end{tabular}

Rs. 114753.34/ milch animal/lactation period. Dung value for the period was found Rs. 4000 that contributed Rs. 9.64 per milch animal (Rs.1.50 per litre of milk) in the profit.

Net income from the livestock rearing in the study area was Rs. 67.87 per day. The net income is closer to the result of a study done earlier in which net return per day was Rs.73.44 of buffalo (Meena and Sharma, 2019). The total maintenance cost per milch animal was Rs. 84978.07 as shown in Table 5. Per day of the cost was Rs. 219.12 which is almost similar to research conducted in Sirsa district of Haryana state. In which overall gross maintenance cost per day was found Rs. 210.29 for crossbred cow and buffalo it was Rs. 203.98 per day (Lal et al., 2016).

For seeing the result of an integrated farming system the whole benefit and cost of the different combinations of crop production per annum with livestock enterprisesare added.In Table 6 different combinations which are taken as cropping patterns per annum are shown. The incomes from those combinations are given in Rs./annum for the study area.

Benefit and cost ratio was calculated which was 1.31 for combination-1 (oilseed + cereal), 1.28 for combination-2 (oilseed + pulse), 1.31 for (pulse + cereal) and 1.28 for combination-4 (pulse + pulse). Then all combinations are farming with adding one more enterprise i.e. livestock shown in Table 7. The B:C ratio for different IFS's were 1.359 for IFS-1, 1.347 for IFS2, 1.360 for IFS-3, and 1.348 for IFS-4 which was The $\mathrm{B}: \mathrm{C}$ ratio with any combination were giving more profit as compared to the cultivation of crops only. IFS-3 (Livestock + pulse + cereal)was a better combination for adaptation as compare to other IFS.

\section{Conclusion:}

Integrated farming system (IFS) showing a good

\begin{tabular}{|c|c|c|c|c|c|c|c|}
\hline \multicolumn{8}{|c|}{$\begin{array}{r}\text { Table 6: Different cropping patterns of crops grown in the study area } \\
\text { Combination- }\end{array}$} \\
\hline & Soybean & Wheat & Total & & Soybean & Gram & Total \\
\hline B & 34645.23 & 64268.78 & 98914.01 & B & 34645.23 & 47543 & 82188.23 \\
\hline $\mathrm{C}$ & 29013.5 & 46171.6 & 75185.1 & $\mathrm{C}$ & 29013.5 & $35,135.23$ & $64,148.73$ \\
\hline \multirow[t]{3}{*}{$\mathrm{B}: \mathrm{C}$} & 1.19411 & 1.39195 & 1.31561 & $\mathrm{~B}: \mathrm{C}$ & 1.19411 & 1.35314 & 1.28121 \\
\hline & \multicolumn{7}{|c|}{ Combination-3Pulse + Cereal (Rs./annum) Combination-4pulse + pulse (Rs./annum.) } \\
\hline & Black Gram & Wheat & Total & & Black Gram & Gram & Total \\
\hline B & 28150.61 & 64268.78 & 92419.39 & B & 28150.61 & 47543 & 75693.61 \\
\hline $\mathrm{C}$ & 24101.12 & 46171.6 & 70272.72 & $\mathrm{C}$ & 24101.12 & $35,135.23$ & $59,236.35$ \\
\hline $\mathrm{B}: \mathrm{C}$ & 1.16802 & 1.39195 & 1.31515 & B:C & 1.16802 & 1.35314 & 1.27782 \\
\hline
\end{tabular}

[B-Benefit (Rs.), C-Cost (Rs.), B:C-Benefit-Cost Ratio] 
Avdhesh Sharma and P. S. Badal

\begin{tabular}{lccc}
\hline \multicolumn{2}{c}{ Table 7 : Different integrated farming systems } & \multicolumn{1}{c}{ Integrated Fam } \\
\hline & Livestock & Combination- & Total \\
\cline { 2 - 4 } $\mathrm{B}$ & 118753.34 & 98914.01 & 217667.35 \\
$\mathrm{C}$ & 84978.07 & 75185.10 & 160163.17 \\
$\mathrm{~B}: \mathrm{C}$ & 1.39745 & 1.31560 & 1.35903 \\
\hline & & & Total \\
\hline & Livestock & Combination-3 & $2,11,172.73$ \\
$\mathrm{~B}$ & $1,18,753.34$ & $92,419.39$ & $1,55,250.79$ \\
$\mathrm{C}$ & $84,978.07$ & $70,272.72$ & 1.36020 \\
$\mathrm{~B}: \mathrm{C}$ & 1.397458 & 1.315153 & \\
\hline Integrated Farming System- 3 & &
\end{tabular}

indication of profit when it was adopted in the study area. IFS (crop+livestock) has proven to be the most viable option representing various combinations. With food security emerging as a major concern during the COVID19 pandemic, the Agriculture Department is promoting the concept of integrated farming systems (IFS) that could help small and marginal farmers in the State by using their land and resources better way.Sustainable agriculture can attain an integrated method to boosting agricultural productivity and resource management that addresses all three important aspects of sustainability: economic, environmental, and social.

\section{REFERENCES}

FAO. (2012). Balanced feeding for improving livestock productivity - Increase in milk production and nutrient use efficiency and decrease in methane emission, by M.R. Garg. FAO Milch Animal Production and Health, 173.

Gupta, V., Rai, P. Kumar and Risam, K. S. (2012). Integrated Crop-Livestock Farming Systems: A Strategy for Resource Conservation and Environmental Sustainability. Indian Research Journal of Extension Education, 2(Special issue): 49-54.

Indira, D. (2017). Integrated Crop-Livestock Farming Systems For The Sustainable Livestock Production. International Journal of Innovative Research and Advanced Studies, 4(6): $117-120$.

Kiran Reddy, G, Govardhan, M., Pragathi Kumari, C., Latheef Pasha, M., Ali Baba, M. and Rani, B. (2020). Integrated Farming System a Promising Farmer and Eco Friendly Approach for Doubling the Farm Income in India-A Review. Int.J.Curr.Microbiol.App.Sci, 9(1): 2243-2252.

Kumar, Sanjeev, Bhatt, B. P., Dey, A., Shivani, Kumar, U., Idris, M., Mishra, J. S. and Kumar, S. (2018). Integrated farming system in India: Current status, scope and future prospects in changing agricultural scenario. Indian Journal

\begin{tabular}{|c|c|c|c|}
\hline \multicolumn{4}{|c|}{ ystem-1 (Rs /ha.) } \\
\hline & Lives tock & Combination- 2 & Total \\
\hline B & 118753.34 & 82188.23 & 200941.57 \\
\hline $\mathrm{C}$ & 84978.07 & 64148.73 & 149126.80 \\
\hline $\mathrm{B}: \mathrm{C}$ & 1.39745 & 1.28121 & 1.34745 \\
\hline & Lives tock & Combination- 4 & Total \\
\hline B & $1,18,753.34$ & $75,693.61$ & $1,94,446.95$ \\
\hline $\mathrm{C}$ & $84,978.07$ & $59,236.35$ & $1,44,214.42$ \\
\hline $\mathrm{B}: \mathrm{C}$ & 1.39745 & 1.27782 & 1.34831 \\
\hline
\end{tabular}

of Agricultural Sciences, 88(11): 1661-1675.

Kumar, Sunil, Ansari, M. Q., Naresh, R. K. and Kumar, V. (2014). Integrating Crop and Livestock Management for Enhanced Productivity, Profitability and Sustainability of The Rice-Wheat System in North West India. International Journal of Life Sciences Biotechnology and Pharma Research, 3(2): 74-84.

Kumawat, R., Singh, N. K. and Lal Meena, C. (2014). Economic Analysis of Cost and Returns of Milk Production, Extent of Adoption of Recommended Management Practices on Sample Dairy Farms in Bikaner District of Rajasthan. Global Journal of Science Frontier Research: D Agriculture and Veterinary, 14(5): 47-53.

Kumbhare, S.L., Sharma, K.N.S. and Patel, R.K. (1983). Standardization of bovine units. Indian J Anim Sci 53: 547

Lal, Priyanka and Chandel, B. S. (2016). Economics of milk production and cost elasticity analysis in Sirsa district of Haryana. Economic Affairs, 61(3): 405-411.

Meena, G. L. and Sharma, L. (2019). An Economic Analysis of Milk Production of Buffalo and Cow in Rajasthan. October.

Rana, S. (2015). Recent Advances in Integrated Farming Systems. In Department of Agronomy, College of Agriculture, CSK Himachal Krishi Vishvavidyalaya, Palampur (Issue January 2015).

Rao, V.M. (1991). Dairy Farming: Socio-economic Analysis of Milk Production. Reliance Publishing House, New Delhi

Reddy, P.P. (2016). Integrated Crop-Livestock Farming Systems. Sustainable Intensification of Crop Production: 357-370.

Singh, H., Sharma, S. K., Dashora, L. N., Burark, S. S. and Meena, G. L. (2013). Characterization and Economics of Farming Systems in Southern Rajasthan. 52(1): 67-70.

Sunil, V. R., Chandel, B. S. and Makarabbi, G. (2019). Economics of Milk Production in Mandya District of Karnataka. Economic Affairs, 61(4): 659-665. 
Tanwar, P. S., Kumar, Y. and Sankhla, G. (2012). Economics of Milk Production Among Member and Non- Production families of Dairy Cooperatives in Jaipur ( Rajasthan ) Families. Indian Journal of Dairy Science, 65(5): 405-409.

Umamageswari, M., Dixit, P. K. and Sivaram, M. (2017). Economics of milk production in Tamil Nadu - a comparative study. Indian Journal of Dairy Science, 70(2): 221-227.
Walia, S. S. and Kaur, N. (2013). Integrated Farming System - An Ecofriendly Approach for Sustainable Agricultural Environment - A Review. Greener Journal of Agronomy, Forestry and Horticulture, 1(1): 001-011.

URL

https://www.indiastat.com/data/agriculture/total-foodgrains/ data-year/2012-2021.

\section{$17^{\text {th }}$ Year}

$\star \star \star \star \star$ of Excellence $\star \star \star \star \star$ 